\title{
EXPERIMENTAL MODELING OF MULTIPLE SCLEROSIS: THE RESULTS OF CORRECTIVE ACTION OF ACTIVE ANTIOXIDANT
}

\author{
I.V. Okunevich
}

Institute of Experimental Medicine, Saint Petersburg, Russia

\section{ЭКСПЕРИМЕНТАЛЬНАЯ МОДЕЛЬ РАССЕЯННОГО СКЛЕРОЗА: РЕЗУЛЬТАТЫ КОРРЕКЦИИ АКТИВНЫМИ АНТИОКСИДАНТАМИ}

\author{
И.В. Окуневич \\ ФГБНУ «Институт экспериментальной медицины», Санкт-Петербург
}

irina_okunevich@mail.ru

Comprehensive treatment of patients with multiple sclerosis (MS) is still relevant. The complex pathogenesis and acute incidence of MS in young people requires the use of multifunctional drugs with a protective effect, including antioxidants. The purpose of this study is to identify a corrective neuroprotective and immune modulating effect of the synthetic drug Triafen-2 (Trf-2), obtained in optimized way. Trf-2 was used at a dose of $50 \mathrm{mg} / \mathrm{kg}$ orally with chronic administration in II parts of experiments. To create an adequate model of MS - autoimmune encephalomyelitis (EAE), immunization of guinea pigs with an encephalitic mixture was used in Freund's complete adjuvant. Mortality, a number of immunological parameters, the clinical picture of neurological complications and the severity of CNS damage in guinea pigs were determined. We studied morphologically the development of T-lymphocytic infiltration of the brain and spinal cord, demyelination of nerve fibers, the degree of cerebellar disorders, disorders of the pelvic organs, the presence of paresis and paralysis. A significant decrease in mortality was shown and protective effect of Trf-2 on neurological symptoms of EAE was noted. The reduction and even complete absence of paresis and paralysis in $66.5 \%$ of guinea pigs in the experimental group compared with animals that did not receive treatment was determined. A positive effect of Trf- 2 on the migration activity of leukocytes and antibodies in the blood was found. In the group with $\operatorname{Trf}-2$, there was a decrease in the content of lipid hydroperoxides and malonic dialdehyde. A pronounced neuroprotective and immune modulating effect of Triafen-2, which inhibits pathological disorders in an experimental model of EAE, has been established. The results justify the need for further study of Triafen-2 as a promising corrective drug.

Keywords: experimental autoimmune encephalomyelitis; Triafen-2; protective effect.

Комплексное лечение больных рассеянным склерозом (РС) остается по-прежнему актуальным. Сложный патогенез и острая заболеваемость РС людей в молодом возрасте требует применения полифункциональных препаратов с защитным действием, включая препараты - антиоксиданты. Целью данного исследования было выявление в эксперименте корректирующего действия у синтетического препарата Триафена-2 (Трф-2), полученного оптимизированным способом. Трф-2 применяли в дозе 50 мг/кг перорально при хроническом введении взрослым морским свинкам в 2-х сериях опытов. Для создания адекватной модели РС - аутоиммунного энцефаломиелита (ЭАЭ) использовали иммунизацию морских свинок энцефалитогенной смесью в полном адъюванте Фрейнда. Определяли летальность, ряд иммунологических показателей, клиническую картину неврологических осложнений и тяжесть поражения ЦНС у морских свинок. Морфологически изучали развитие Т-лимфоцитарной инфильтрации головного и спинного мозга, демиелинизацию нервных волокон, степень мозжечковых расстройств, нарушения тазовых органов, наличие парезов и параличей. Показано значительное снижение летальности и отмечено выраженное протективное действие препарата Трф-2 на неврологическую симптоматику ЭАЭ. Определено снижение парезов и параличей у $66,5 \%$ морских свинок в группе ЭАЭ+Трф-2по сравнению с животными, не получавшими лечения. Обнаружено положительное влияние Трф-2 на миграционную активность лейкоцитов и антитела в крови. В группе животных, получавших Трф-2, отмечено снижение содержания гидроперекисей липидов и малонового диальдегида. Установлено выраженное нейропротективное и иммуномодулирующее действие препарата Триафена-2, который тормозит патологические нарушения в условиях экспериментальной модели ЭАЭ. Полученные результаты обосновывают необходимость дальнейшего изучения Триафена-2 в качестве перспективного корректирующего средства.

Ключевые слова: экспериментальный аутоиммунный энцефаломиелит; антиоксидант триафен; протективное действие.

Introduction. The main therapy of multiple sclerosis (MS) patients is aimed at stopping the autoimmune inflammatory process by immune modulating and anti-inflammatory drugs, since it is destructive damage to the myelin sheaths of the

nerve fibers by the own immune system that leads to the development of neurological complications [1]. The multiplicity of regimens of MS dictates the need of new effective drugs. Due to the activation of oxidative stress in the complex therapy of MS, 
the use of multifunctional drugs with antioxidant effect is justified. Earlier, we detected anti-inflammatory activity in antioxidant Hypoxen (Hpx) [2]. We explored another active compound - Triafen-2 (Trf-2) - the analog of Hpx, obtained in optimized way. Aim of the study - to identify the ability of Trf-2 to correct of immunological and neurological complications in the MS model.

Material and methods. The model of experimental autoimmune encephalitis (EAE) was used as the most adequate method of MS reproduction, which allows studying pathological processes in CNS. EAE was caused by a single subcutaneous inoculation into the paw pads of guinea pigs of encephalitogenic mixture - the main myelin protein in complete Freund's adjuvant. A few days later the animals developed T-lymphocytic infiltration of the brain, demyelination of the nerve endings and paralysis occurred. The drug Trf- 2 was orally administered at a dose of $50 \mathrm{mg} / \mathrm{kg}$ daily for 35 days. The experiments were carried out in I-II parts on 75 adult male guinea pigs $(400-450 \mathrm{~g})$. In part I, in 30 guinea pigs, mortality was determined after the inoculation of sensitizing agent and adding of Trf-2 was evaluated. In part II of experiments, a study was conducted on the effectiveness of Trf- 2 in 45 guinea pigs, which were divided into 3 groups: 1 - intact, 2 - pathological model (EAE), 3 EAE + Trf-2. The severity of the disease was assessed by clinical index in points from 0 to 6 . Presence of paresis and paralysis in animals were found. Neurological symptoms and the state of the nerve endings of the peripheral and central parts of CNS were studied morphologically. After immunization, blood samples were taken from guinea pigs 5 times for testing for antibodies against myelin basic protein. The migration activity of peripheral blood leukocytes were evaluated after incubation of heparinized blood at $37^{\circ} \mathrm{C}$ for 24 hours. Guinea pigs were removed from the experiment by rapid decapitation. In the blood serum the content of lipid peroxidation products - hydroperoxides and malonic dialdehyde was studied.

Results and discussion. A single injection of the immunizing mixture caused the incidence of morbidity in $100 \%$ of the guinea pigs of EAE group. This led to the appearance of characteristic neurological symptoms: ataxia, motor paresis and paralysis, pelvic organ disorders, cerebellar disorders. The clinical index at the peak of the disease was 4.6 points, the cumulative index of $53.1 \%$, which characterized the course of EAE in this experience as severe. Mortality in the control group (EAE) was $30 \%$. In the group of animals receiving drug Trf- 2 only $6.6 \%$ of the animals died. In the II series of experiments, as a result of drug administration of guinea pigs (EAE $+\operatorname{Trf}-2)$, only 5 individuals showed clinical signs of damage. The number of limb paralysis was $73.5 \%$ lower than in the group with pathology. It is important that in 10 guinea pigs $(66.5 \%)$ of the group receiving $\operatorname{Trf}-2$, there were no neurological disorders at all. For pathological changes in the CNS in EAE group of animals was characterized by demyelination of the nerves, most pronounced in the spinal cord and, especially, in the lumbosacral region. Inflammatory infiltration consisted mainly of monocytes and lymphocytes in the lumbosacral spinal cord and in the interior of the white matter of the brain in animals with Trf-2, the greatest safety of the myelin sheaths of neurons was found. In the group of animals treated with $\operatorname{Trf}-2$, the frequency of detection of circulating complexes was the smallest, and the peak production of antibodies fell on the $21^{\text {st }}$ day. The size of the migration zones of immunocompetent cells prevailed in the pathological group (EAE). The results obtained indicate the available immune protective ability of Trf-2. When analyzing the peripheral blood of experimental guinea pigs, decline of the accumulation of content: MDA $(-30 \%)$ and hydro-peroxides $(-29 \%)$ in group with Trf-2 treatment was shown.

Conclusion. The pathological process in MS complex in nature and course, autoimmune reactions cause an inflammatory process and lead to diffuse degenerative changes in axons and neuron death, an excessive concentration of reactive oxygen forms and oxidative products occur. The model of EAE was the most adequate of MS reproduction and allowed to investigate new protective drugs.

Findings. In the group of animals with the drug Trf-2, there were more surviving healthy guinea pigs and individuals with a minimum of neurological complications of modeling MS disorder. This suggests the presence of a protective neurological effect in tested drug Trf-2.

The results indicate in the ability of Trf- 2 to reduce the degree of oxidative stress - in a few lipid per oxidative products. The corrective action of Trf-2 is based on the antioxidant and antiinflammatory properties of this drug. We expect that the search of new multifunctional drug with protective effects as Trf-2 will be useful.

I express my profound gratitude to the staff of the immunology department for collaboration and methodological assistance.

\section{References}

1. Sternberg Z. Promoting sympathovagal balance in multiple sclerosis; pharmacological, non-pharmacological, and surgical strategies. Autoimmunity Reviews. 2016; 5(6):113-123. https://doi.org/10.1016/j. autrev.2015.04.012.

2. Khnychenko LK, Okunevich IV Experimental assessment of inflammatory effect of hypoxen. Reviews on clinical pharmacology and drug therapy. 2015:13(3): 35-38. (In Russ.). https://doi.org/10.17816/RCF1335-38. 